\title{
Two Types of Hynobius naevius from the Central Region of Kyushu Island, Japan (Caudata: Hynobiidae)
}

\section{AUTHOR(S):}

SAKAMOTO, MARIKO; NISHIKAWA, KANTO; MATSUI, MASAFUMI

\section{CITATION:}

SAKAMOTO, MARIKO ...[et al]. Two Types of Hynobius naevius from the Central Region of Kyushu Island, Japan (Caudata: Hynobiidae). Current Herpetology 2005, 24(2): 67-77

\section{ISSUE DATE:}

2005-12

URL:

http://hdl.handle.net/2433/216877

RIGHT:

(C) 2005 by The Herpetological Society of Japan 


\title{
Two Types of Hynobius naevius from the Central Region of Kyushu Island, Japan (Caudata: Hynobiidae)
}

\author{
Author(s): MARIKO SAKAMOTO, KANTO NISHIKAWA, MASAFUMI MATSUI
}

Source: Current Herpetology, 24(2):67-77.

Published By: The Herpetological Society of Japan

DOI: http://dx.doi.org/10.3105/1345-5834(2005)24[67:TTOHNF]2.0.CO;2

URL: http://www.bioone.org/doi/

full/10.3105/1345-5834\%282005\%2924\%5B67\%3ATTOHNF\%5D2.0.CO\%3B2

BioOne (www.bioone.org) is a nonprofit, online aggregation of core research in the biological, ecological, and environmental sciences. BioOne provides a sustainable online platform for over 170 journals and books published by nonprofit societies, associations, museums, institutions, and presses.

Your use of this PDF, the BioOne Web site, and all posted and associated content indicates your acceptance of BioOne's Terms of Use, available at www.bioone.org/page/terms_of_use.

Usage of BioOne content is strictly limited to personal, educational, and non-commercial use. Commercial inquiries or rights and permissions requests should be directed to the individual publisher as copyright holder. 


\title{
Two Types of Hynobius naevius from the Central Region of Kyushu Island, Japan (Caudata: Hynobiidae)
}

\author{
MARIKO SAKAMOTO $^{1 *}$, KANTO NISHIKAWA ${ }^{2}$, AND MASAFUMI MATSUI $^{2}$ \\ ${ }^{1}$ Graduate School of Science and Technology, Kumamoto University, Kumamoto 860- \\ 8555, JAPAN \\ ${ }^{2}$ Graduate School of Human and Environmental Studies, Kyoto University, Kyoto 606- \\ 8501, JAPAN
}

\begin{abstract}
We surveyed allozymic variation among Hynobius naevius from 11 localities of central Kyushu, Japan. The results revealed the presence of two genetic groups (I and II) that exhibited a great difference in allelic frequency and a large genetic distance. Specimens from seven of the 11 localities invariably belonged to Group I, and those from three other localities belonged to Group II. In the remaining one locality, representatives of both of these two groups were found just as in northern Kyushu. The two genetic groups also differed in morphological (Group I larger than Group II in body size) and ecological characters (breeding sites located in open streams in Group I, but possibly in underground water in Group II). These differences might have been enabling them to coexist.
\end{abstract}

Key words: Allozymic variation; Caudata; Central Kyushu; Hynobius naevius; Sympatry

\section{INTRODUCTION}

Hynobius naevius is a lotic-breeding salamander inhabiting wide areas in southwestern Japan. This species has long been known to exhibit extensive morphological variations (Sato, 1943), and Sato et al. (1994) recognized three distinct morphotypes within Kyushu (northern, central, and southern Kyushu types). However, Tominaga et al. (2003) found sympatric occurrences of the northern and southern Kyushu types of Sato et al. (1994) in a certain region of northern Kyushu and docu-

\footnotetext{
* Corresponding author. Tel: +81-96-342-3448;

Fax: +81-96-342-3448;

E-mail address: naevius4mari@ybb.ne.jp
}

mented their morphological divergences (a relatively large body and unmottled dorsum in the northern type, and a smaller body and mottled dorsum in the southern type). Tominaga et al. (2003) also clarified genetic differentiation between the two morphotypes. On the other hand, these authors rejected the validity of the central Kyushu type of Sato et al. (1994), which was reported to have a relatively large body and mottled dorsal pattern.

The island of Kyushu can be roughly divided into northern, central, and southern regions on the basis of geological, geographical, and topographical differences. Of these, the central region is famous for its volcanoes extending from east to west along the BeppuShimabara Graben. Whether the central 
Kyushu type of $H$. naevius is valid as Sato et al. (1994) proposed or invalid as Tominaga et al. (2003) claimed is an interesting problem from the viewpoint of physiographic features of the central Kyushu region. At the same time, the sympatric occurrences of the northern and southern Kyushu types in northern Kyushu (Tominaga et al., 2003) suggest the presence of a similar situation in central Kyushu.

To estimate the evolutionary history of $H$. naevius within Kyushu, it is necessary to elucidate the geographic genetic structure, and the patterns of morphological and ecological diversity in this species from central and southern Kyushu, for which relevant information is still insufficient (Tominaga et al., 2003).

Bearing these things in mind, we surveyed genetic variation in $H$. naevius from central Kyushu. In addition, we attempted to infer the origin of the $H$. naevius population inhabiting the inside slope of the caldera rim of Aso Volcano. As mentioned above, central Kyushu is characterized by volcanoes and is supposed to have undergone the most extensive geological environmental changes in Kyushu. For example, Aso Volcano, world-famous for its large caldera, is known to have had four major eruptions of extraordinarily large scale from approximately 270,000 to 85,000 years ago (Machida et al., 2001), and a part of its central cone still remains active. Nevertheless, a population of $H$. naevius inhabits the inside slope of the caldera rim of this volcano as the only salamander there. We tried to clarify the origin of this population by surveying its genetic relationships with populations from surrounding areas.

\section{MATERIALS AND METHODS}

We made field surveys for a total of 53 days between April 2002 and January 2004 at 19 localities in central Kyushu (Fig. 1; Table 1), where $H$. naevius was expected to occur.

We searched under stones and dead leaves at the bottom and on the banks of small streams and surrounding slopes $(<45 \mathrm{~m}$ from the

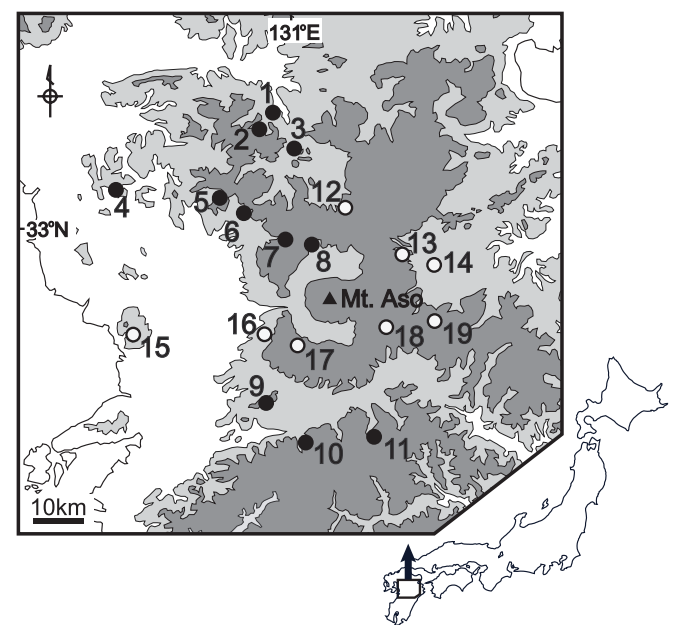

FIG. 1. A map of central Kyushu, showing localities surveyed in the present study. Locality numbers correspond to those listed in Table 1 . Closed and open circles indicate localities visited, where salamanders were found and not found, respectively. Light gray and dark gray areas indicate $\geqq 200 \mathrm{~m}$ a.s.l. and $\geqq 600 \mathrm{~m}$ a.s.l., respectively.

stream), to collect larvae and metamorphs. From March to May 2003, we tried to find eggs in the open mountain streams (1.5-4 $\mathrm{m}$ in width) and in underground streams (ca. $1 \mathrm{~m}$ below the ground). From June to October 2003, we searched for individuals just after metamorphosis by turning stones and leaves on banks of mountain streams and also by digging the ground of slopes along the streams ( $<60 \mathrm{~cm}$ below the ground). We also searched for overwintering larvae in mountain streams from December 2003 to January 2004. We recorded the microhabitat of each individual on the basis of distance from the mountain stream, depth from the ground surface, and size of stones at the place where we encountered it.

A total of 176 specimens of $H$. naevius from 11 localities (Table 1), including both larvae and metamorphs (juveniles and adults), were used for genetic analyses. Salamanders were anesthetized with chloretone (acetone chloroform) saturated solution, and their livers were removed and maintained frozen at $-80 \mathrm{C}$ until use for electrophoresis. At the same time, we 
TABLE 1. Sampling localities, sample size, and morphological/genetic groups (see text) of samples/ subsamples of Hynobius naevius examined. $\mathrm{BLF}=$ broadleaf forest, $\mathrm{JCF}=\mathrm{Japanese}$ cedar forest.

\begin{tabular}{|c|c|c|c|c|c|c|c|}
\hline \multirow{2}{*}{$\begin{array}{c}\text { Sample } \\
\text { /subsample }\end{array}$} & \multirow{2}{*}{ Locality } & \multirow{2}{*}{ Altitude (m) } & \multirow{2}{*}{ Forest type } & \multicolumn{3}{|c|}{ Sample size } & \multirow{2}{*}{ Group } \\
\hline & & & & $\overline{\text { Larvae }}$ & tamo & $\overline{\text { Total }}$ & \\
\hline 1 & Oyama-machi, Hita-shi, Oita Pref. & $300-350$ & $\begin{array}{c}\text { BLF } \\
\text { (partially JCF) }\end{array}$ & 36 & 8 & 44 & I \\
\hline 2 & Maetsue-mura, Hita-shi, Oita Pref. & $340-380$ & $\mathrm{JCF}$ and BLF & 18 & 7 & 25 & I \\
\hline 3 & Oguni-machi, Kumamoto Pref. & 320 & JCF & 15 & - & 15 & I \\
\hline 4 & Mikawa-machi, Kumamoto Pref. & $240-320$ & $\begin{array}{c}\text { JCF } \\
\text { (partially BLF) }\end{array}$ & 8 & - & 8 & I \\
\hline $5-1$ & $\begin{array}{l}\text { Kikuka-machi, Yamaga-shi, } \\
\text { Kumamoto Pref. }\end{array}$ & $500-650$ & $\begin{array}{c}\text { BLF } \\
\text { (partially JCF) }\end{array}$ & 16 & 8 & 24 & I \\
\hline $5-2$ & $\begin{array}{l}\text { Kikuka-machi, Yamaga-shi, } \\
\text { Kumamoto Pref. }\end{array}$ & $600-650$ & $\begin{array}{c}\text { BLF } \\
\text { (partially JCF) }\end{array}$ & - & 3 & 3 & II \\
\hline 6 & Kikuchi-shi, Kumamoto Pref. & 300 & $\begin{array}{c}\text { JCF } \\
\text { (partially BLF) }\end{array}$ & 1 & - & 1 & I \\
\hline 7 & $\begin{array}{l}\text { Kikuchi-keikoku, Kikuchi-shi, } \\
\text { Kumamoto Pref. }\end{array}$ & $600-650$ & BLF & 13 & 1 & 14 & I \\
\hline 8 & Aso-machi, Aso-shi, Kumamoto Pref. & $560-660$ & JCF & 21 & 2 & 23 & I \\
\hline 9 & $\begin{array}{l}\text { Yamato-cho (formerly Yabe-machi), } \\
\text { Kumamoto Pref. }\end{array}$ & $640-700$ & $\begin{array}{c}\mathrm{JCF} \\
\text { (partially BLF) }\end{array}$ & - & 10 & 10 & II \\
\hline 10 & $\begin{array}{l}\text { Yamato-cho (formerly Yabe-machi), } \\
\text { Kumamoto Pref. }\end{array}$ & $740-880$ & $\begin{array}{c}\mathrm{JCF} \\
\text { (partially BLF) }\end{array}$ & - & 8 & 8 & II \\
\hline 11 & $\begin{array}{l}\text { Yamato-cho (formerly Seiwa-son), } \\
\text { Kumamoto Pref. }\end{array}$ & 810 & BLF & - & 1 & 1 & II \\
\hline 12 & Minamioguni-machi, Kumamoto Pref. & $580-640$ & $\begin{array}{c}\text { JCF } \\
\text { (partially BLF) }\end{array}$ & - & - & - & - \\
\hline 13 & Ubuyama-mura, Kumamoto Pref. & $460-520$ & JCF & - & - & - & - \\
\hline 14 & Taketa-shi, Oita Pref. & $320-400$ & $\begin{array}{c}\text { JCF } \\
\text { (partially BLF) }\end{array}$ & - & - & - & - \\
\hline 15 & Kumamoto-shi, Kumamoto Pref. & $400-500$ & JCF & - & - & - & - \\
\hline 16 & Nishihara-mura, Kumamoto Pref. & $370-410$ & BLF & - & - & - & - \\
\hline 17 & $\begin{array}{l}\text { Minamiaso-mura (formerly kugino-mura), } \\
\text { Kumamoto Pref. }\end{array}$ & $1040-1080$ & BLF & - & - & - & - \\
\hline 18 & Takamori-machi, Kumamoto Pref. & $600-700$ & BLF & - & - & - & - \\
\hline 19 & Takamori-machi, Kumamoto Pref. & $900-950$ & BLF & - & - & - & - \\
\hline
\end{tabular}

examined sex and maturity of each specimen by observing the gonads. Voucher specimens, fixed in $10 \%$ formalin and later preserved in $70 \%$ and $50 \%$ ethanol for metamorphs and larvae, respectively, are stored in Sakamoto's private collection.

Homogenized tissue extracts were analyzed by standard horizontal starch gel electrophoresis (Ayala et al., 1972; Shaw and Prasad, 1970) using Starch Art (Otto Hiler, Madison, Wisconsin, USA) and starch from potatoes
(Fluka Chemie GmbH, CH-9471 Buchs, Switzerland) mixed in a 1:1 ratio and then suspended in buffer at a concentration of $12 \%$.

Staining methods followed Shaw and Prasad (1970) and Harris and Hopkinson (1976). Genetic interpretations of allozyme-bands were based on criteria developed by Selander et al. (1971). Enzyme nomenclature, E.C. numbers, and the notation of loci, electromorphs, and genotypes mainly follow Murphy et al. (1996) 
TABLE 2. Enzymes, presumptive loci, and buffer systems used in the analyses of allozyme variations among samples/subsamples of Hynobius naevius.

\begin{tabular}{llll}
\hline Enzyme & E.C. number & Locus & Buffer systems* \\
\hline Aconitate hydratase & 4.2 .1 .3 & ACOH-A & TC8 \\
Aconitate hydratase & 4.2 .1 .3 & ACOH-B & TC8 \\
Aspartate transaminase & 2.6 .1 .1 & ATA-A & CAPM6 \\
Aspartate transaminase & 2.6 .1 .1 & ATA-B & CAPM6, TC7 \\
Glucose-6-phosphate isomerase & 5.3 .1 .9 & GPI-A & CAPM6 \\
Glutamate dehydrogenase & 1.4 .1 .3 & GTDH-A & TC8 \\
Glycerol-3-phosphate dehydrogenase & 1.1 .1 .8 & G3PDH-A & TC8 \\
Isocitrate dehydrogenase & 1.1 .1 .42 & IDH-A & TC7 \\
Isocitrate dehydrogenase & 1.1 .1 .42 & IDH-B & TC7 \\
L-Lactate dehydrogenase & 1.1 .1 .27 & LDH-A & CAPM6, TC7 \\
L-Lactate dehydrogenase & 1.1 .1 .27 & LDH-B & CAPM6, TC7 \\
Malate dehydrogenase & 1.1 .1 .37 & MDH-A & CAPM6, TC8 \\
Malate dehydrogenase & 1.1 .1 .37 & MDH-B & CAPM6, TC8 \\
Malic enzyme** & 1.1 .1 .40 & MDHP-A & TC7 \\
Malic enzyme** & 1.1 .1 .40 & MDHP-B & TC7 \\
Phosphoglucomutase & 5.4 .2 .2 & PGM-A & TC7 \\
Phosphoglucomutase & 5.4 .2 .2 & PGM-C & TC7 \\
Phosphogluconate dehydrogenase & 1.1 .1 .44 & PGDH-A & TC7 \\
\hline
\end{tabular}

* CAPM6: Citrate-aminopropylmorpholine, $\mathrm{pH}=6.0$ (Clayton and Tretiak, 1972). TC7: Tris-citrate, $\mathrm{pH}=7.0$ (Shaw and Prasad, 1970), TC8: Tris-citrate, $\mathrm{pH}=8.0$ (Clayton and Tretiak, 1972), TBE8.7: Trisborate-EDTA, $\mathrm{pH}=8.7$ (Boyer et al., 1963). ** NADP-dependent malate dehydrogenase.

and IUBM (1992). Electromorphs were designated by letters with "a" representing the most rapidly migrating variant.

We examined 18 presumptive loci encoding 11 enzyme systems (Table 2) and analyzed data using the BIOSYS-1 program package (Swofford and Selander, 1981). Standard estimates of genetic variability, i.e., mean heterozyosity by direct count $(\mathrm{H})$, proportion of polymorphic loci $(\mathrm{P})$, and the mean number of alleles per locus (A), were computed for each sample. Variable loci were checked by goodness-of-fit tests to determine whether they were in Hardy-Weinberg equilibrium in each sample. The expected numbers of each genotype were calculated using Levene's (1949) formulae for small samples.

Using samples of sufficiently large size [Sample 1 (OYAMA), Sample 2 (MAETSUE), and Subsample 5-1 (a part of KIKUKA: see below)], we first compared allele frequencies between metamorphs and larvae within a sample, and found no significant differences between them. Therefore, we combined data for metamorphs and larvae from the same locality in the subsequent analyses.

In order to estimate overall genetic differentiation among samples, we calculated Nei's unbiased genetic distance (Nei, 1978) and modified Rogers' (Wright, 1978) distance. Patterns of genetic similarities and dissimilarities among samples were inferred by the UPGMA clustering algorithm with Nei's (1978) distance (Sneath and Sokal, 1973) and the Neighbor-joining (NJ) method (Saitou and Nei, 1987) based on the modified Rogers' distance (Wright, 1978). These analyses were performed by use of the BIOSYS-1 (Swofford and Selander, 1981) and PHYLIP ver. 3.5C (Felsenstein, 1993), respectively. 


\section{RESULTS}

\section{Field observations}

We collected salamanders at 11 of 19 localities surveyed (Fig. 1, Table 1). We failed to find salamanders in the remaining eight localities including locality 12 , where larval $H$. naevius was recorded in 1960 (Environmental Agency of Japan, 1979). In our field observations from March to May, we found two groups of adult salamanders that differ in morphology and habitat type (Table 1). Adults collected under stones and dead leaves in mountain streams (1.5-4 $\mathrm{m}$ in width) and on their banks tended to be larger in body size (average snout-vent length $[\mathrm{SVL}]=72.1 \mathrm{~mm}$ ) and lacked mottling on the bluish purple dorsum, while those collected from slopes outside the streams were smaller (average $\mathrm{SVL}=$ $63.9 \mathrm{~mm}$ ) with brownish white mottling on a reddish purple dorsum. Adult salamanders of this smaller type were found $5-30 \mathrm{~cm}$ below the ground densely covered by stones on slopes, 4-23 $\mathrm{m}$ away from the streams. Localities $1,2,7$, and 8 were occupied only by salamanders of the larger type, while localities
9, 10 , and 11 were occupied by those of the smaller type. In locality 5 (KIKUKA), both types were found. We failed to find metamorphs in localities 3, 4, and 6 . We found no eggs of $H$. naevius in any of the localities we surveyed, although some females of both the larger and smaller types had mature eggs in their abdomen.

From March to May, we found larval salamanders under stones and dead leaves in the streams of localities 1, 2, 3, 5, 7, and 8 . Because they were large (total length $>50 \mathrm{~mm}$ ) and seemingly well-grown, we supposed them to have hatched in the previous year and to have overwintered in these streams. From July to September, we also found larvae in localities $1-8$, but failed to find them in the remaining localities. We found larvae in locality 5 , but failed to find them in localities 9 and 10 in winter (December-January).

All these larvae lacked claw-like structures on the tips of their digits and thus were identified as $H$. naevius, because larvae of the other lotic-breeding salamanders from Kyushu $(H$. boulengeri and $H$. stejnegeri) have these structures (Sato, 1943; Sato, 1954, 2003).
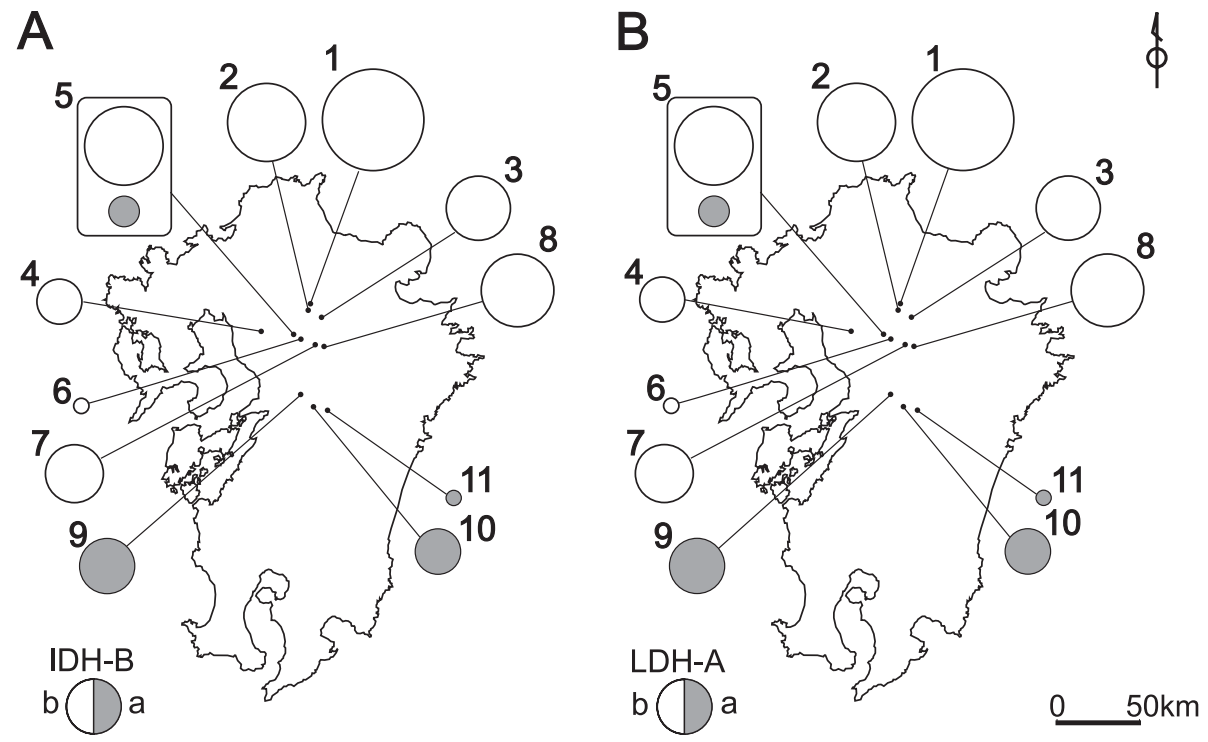

FIG. 2. Allelic frequencies at IDH-B (A) and LDH-A (B) loci in samples of Hynobius naevius from 11 localities of central Kyushu. Locality numbers correspond to those in Table 1. 
TABLE 3. Allele frequencies for polymorphic loci resolved and genetic variability at 18 loci in the samples of Hynobius naevius. $\mathrm{A}=$ mean number of alleles per locus; $\mathrm{P}=$ percentage of polymorphic loci; $\mathrm{H}=$ mean heterozygosity by direct count. For population/subpopulation number, refer to Table 1 and text.

\begin{tabular}{|c|c|c|c|c|c|c|c|c|c|c|c|c|c|}
\hline \multirow[b]{2}{*}{ Locus } & \multirow[b]{2}{*}{ (alleles) } & \multicolumn{12}{|c|}{ Sample/subsample (n) } \\
\hline & & $1(44)$ & $2(25)$ & $3(15)$ & $4(8)$ & $5-1(24)$ & $5-2(3)$ & $6(1)$ & $7(14)$ & $8(23)$ & $9(10)$ & $10(8)$ & $11(1)$ \\
\hline \multirow[t]{2}{*}{$\mathrm{ACOH}-\mathrm{A}$} & $\mathrm{a}$ & 0.011 & & & 0.125 & 0.083 & 0.833 & & 0.214 & 0.109 & 0.350 & 0.188 & \\
\hline & $\mathrm{b}$ & 0.989 & 1.000 & 1.000 & 0.875 & 0.917 & 0.167 & 1.000 & 0.786 & 0.891 & 0.650 & 0.812 & 1.000 \\
\hline \multirow{4}{*}{ ACOH-B } & $\mathrm{a}$ & & & & & 0.063 & 0.667 & & 0.036 & & 0.300 & 0.438 & \\
\hline & $\mathrm{b}$ & 0.045 & 0.060 & 0.100 & 0.313 & 0.500 & 0.333 & 0.500 & 0.393 & 0.283 & 0.700 & 0.562 & 0.500 \\
\hline & $\mathrm{c}$ & 0.955 & 0.940 & 0.767 & 0.437 & 0.354 & & & 0.571 & 0.717 & & & 0.500 \\
\hline & d & & & 0.133 & 0.250 & 0.083 & & 0.500 & & & & & \\
\hline \multirow[t]{3}{*}{ ATA-A } & $\mathrm{a}$ & 0.205 & 0.020 & & & & & & & & & & \\
\hline & $\mathrm{b}$ & 0.795 & 0.840 & 1.000 & 1.000 & 1.000 & 1.000 & 1.000 & 1.000 & 1.000 & 1.000 & 1.000 & 1.000 \\
\hline & c & & 0.140 & & & & & & & & & & \\
\hline \multirow[t]{2}{*}{ ATA-B } & $\mathrm{a}$ & 1.000 & 0.980 & 1.000 & 1.000 & 1.000 & 1.000 & 1.000 & 1.000 & 1.000 & 1.000 & 0.812 & 1.000 \\
\hline & b & & 0.020 & & & & & & & & & 0.188 & \\
\hline \multirow[t]{2}{*}{ GPI-A } & $\mathrm{a}$ & 1.000 & 1.000 & 0.833 & 1.000 & 0.854 & 1.000 & 1.000 & 1.000 & 1.000 & 1.000 & 0.937 & 0.500 \\
\hline & $\mathrm{b}$ & & & 0.167 & & 0.146 & & & & & & 0.063 & 0.500 \\
\hline \multirow[t]{2}{*}{ GTDH-A } & $\mathrm{a}$ & 0.977 & 1.000 & 1.000 & 1.000 & 1.000 & 1.000 & 1.000 & 1.000 & 1.000 & 1.000 & 1.000 & 1.000 \\
\hline & b & 0.023 & & & & & & & & & & & \\
\hline \multirow[t]{2}{*}{ G3PDH-A } & $\mathrm{a}$ & 0.989 & 1.000 & 0.967 & 1.000 & 0.979 & & 1.000 & 1.000 & 1.000 & & & \\
\hline & b & 0.011 & & 0.033 & & 0.021 & 1.000 & & & & 1.000 & 1.000 & 1.000 \\
\hline IDH-A & $\mathrm{a}$ & 1.000 & 1.000 & 1.000 & 1.000 & 1.000 & 1.000 & 1.000 & 1.000 & 1.000 & 1.000 & 1.000 & 1.000 \\
\hline \multirow[t]{2}{*}{ IDH-B } & $\mathrm{a}$ & & & & & & 1.000 & & & & 1.000 & 1.000 & 1.000 \\
\hline & b & 1.000 & 1.000 & 1.000 & 1.000 & 1.000 & & 1.000 & 1.000 & 1.000 & & & \\
\hline \multirow[t]{2}{*}{ LDH-A } & $\mathrm{a}$ & & & & & & 1.000 & & & & 1.000 & 1.000 & 1.000 \\
\hline & $\mathrm{b}$ & 1.000 & 1.000 & 1.000 & 1.000 & 1.000 & & 1.000 & 1.000 & 1.000 & & & \\
\hline \multirow{3}{*}{ LDH-B } & $\mathrm{a}$ & & & & & 0.083 & 1.000 & & & & 1.000 & 1.000 & 1.000 \\
\hline & b & 0.989 & 0.880 & 1.000 & 1.000 & 0.917 & & 1.000 & 1.000 & 1.000 & & & \\
\hline & c & 0.011 & 0.120 & & & & & & & & & & \\
\hline \multirow[t]{3}{*}{ MDH-A } & $\mathrm{a}$ & & 0.060 & & & & & & & & & & \\
\hline & b & 1.000 & 0.940 & 1.000 & 0.500 & 1.000 & & 1.000 & 1.000 & 1.000 & 0.150 & & \\
\hline & c & & & & 0.500 & & 1.000 & & & & 0.850 & 1.000 & 1.000 \\
\hline \multirow[t]{3}{*}{ MDH-B } & $\mathrm{a}$ & 0.023 & 0.040 & & & & & 0.500 & 0.321 & 0.283 & 0.000 & 0.063 & \\
\hline & $\mathrm{b}$ & 0.511 & 0.440 & 0.933 & & 0.833 & 1.000 & & 0.679 & 0.717 & 0.900 & 0.937 & 1.000 \\
\hline & c & 0.466 & 0.520 & 0.067 & 1.000 & 0.167 & & 0.500 & & & 0.100 & & \\
\hline \multirow[t]{3}{*}{ MDHP-A } & $\mathrm{a}$ & 0.159 & 0.220 & & 0.500 & 0.625 & & & 0.179 & 0.065 & & 0.063 & \\
\hline & b & 0.841 & 0.740 & 0.533 & 0.500 & 0.375 & & 1.000 & 0.821 & 0.935 & & 0.375 & \\
\hline & c & & 0.040 & 0.467 & & & 1.000 & & & & 1.000 & 0.562 & 1.000 \\
\hline \multirow[t]{3}{*}{ MDHP-B } & $\mathrm{a}$ & & 0.040 & & & & & & & 0.022 & & & \\
\hline & b & 1.000 & 0.920 & 1.000 & 1.000 & 1.000 & 1.000 & 1.000 & 1.000 & 0.978 & 1.000 & 1.000 & 1.000 \\
\hline & $\mathrm{c}$ & & 0.040 & & & & & & & & & & \\
\hline PGM-A & $\mathrm{a}$ & 1.000 & 1.000 & 1.000 & 1.000 & 1.000 & 1.000 & 1.000 & 1.000 & 1.000 & 1.000 & 1.000 & 1.000 \\
\hline \multirow{4}{*}{ PGM-C } & $\mathrm{a}$ & & & & & & 0.833 & & & & 0.400 & 0.812 & 0.500 \\
\hline & b & 0.045 & 0.020 & 0.600 & 0.250 & 0.229 & 0.167 & 0.500 & 0.429 & 0.413 & 0.600 & 0.188 & \\
\hline & $\mathrm{c}$ & 0.955 & 0.920 & 0.400 & 0.750 & 0.771 & & 0.500 & 0.571 & 0.587 & & & 0.500 \\
\hline & d & & 0.060 & & & & & & & & & & \\
\hline PGDH-A & a & 1.000 & 0.980 & 1.000 & 1.000 & 1.000 & & 1.000 & 1.000 & 1.000 & & & \\
\hline & $\mathrm{b}$ & & 0.020 & & & & 1.000 & & & & 1.000 & 1.000 & 1.000 \\
\hline A & & 1 & 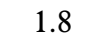 & & & & & & 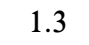 & 1.5 & 1.3 & 1.4 & 1.2 \\
\hline $\mathrm{P}$ & & 16.7 & 44.1 & 27.8 & 27.8 & 38.9 & 16.7 & 16.7 & 27.8 & 27.8 & 27.8 & 38.9 & 16.7 \\
\hline $\mathrm{H}$ & & 0.063 & 0.102 & 0.085 & 0.09 & 0.058 & 0.074 & 0.167 & 0.075 & 0.048 & 0.056 & 0.069 & 0.167 \\
\hline
\end{tabular}


In summary, in localities where metamorphs of the larger type were found (localities 1, 2, 5, 7 , and 8 ), larvae were also seen, while larvae were not found in any season where metamorphs of only the smaller type were found $(9,10)$. In localities 3, 4, and 6, only larval forms were found and these were similar to larvae collected from other localities. Metamorphs of both the larger and smaller types were found in locality 5 , but only one type of larvae similar to those from other localities was found there.

\section{Allozymic variation}

We have scored genotypes at all loci for all individuals examined. In all samples but that from locality 5 (KIKUKA=Sample 5), genotype frequencies agreed well with the HardyWeinberg expectation $(\mathrm{P}>0.05)$ for all polymorphic loci. In contrast, genotype frequency in Sample 5 deviated significantly from the Hardy-Weinberg expectation at all polymorphic loci, and exhibited a low $\mathrm{H}(0.060)$ and high $\mathrm{P}$ values (66.7). Based on allele composition at four loci (IDH-B, LDH-A, MDH-A, and PGDH-A), this sample was unequivocally divided into two subsamples (hereafter referred to as Subsamples 5-1 and 5-2). Genotypic frequencies in each subsample exhibited better fitting to the Hardy-Weinberg expectation than those in the whole Sample 5. These results indicated that Sample 5 included at least two reproductively exclusive units as represented by the two subsamples.

The ten samples and two subsamples were divided into two groups by clear differences in allelic frequencies at eight loci, including complete allelic displacement at two loci (Fig. 2 , Table 3). One group (hereafter referred to as Group I) consisted of Samples 1, 2, 3, 4, 6, 7 and 8, and Subsample 5-1, and the other group (Group II) consisted of Samples 9, 10 and 11, and Subsample 5-2. The two subsamples (5-1 and 5-2) greatly differed in the allelic frequencies at nine loci, of which four lacked heterozygotes and were completely displaced between them. All larvae collected were assigned to Group I.

Table 4 presents two genetic distance coefficients for pairwise comparisons of samples and subsamples (Nei, 1978; Wright, 1978). Because Samples 6 and 11 consisted of only one individual (Table 1), we excluded these samples from genetic distance calculations. Nei's (1978) $\mathrm{D}$ value ranged from 0.000 to 0.801 , with the highest D value between Sample 1 and Subsample 5-2. Between Groups I and II, values for both genetic distances were invariably large. In both UPGMA and NJ phenograms constructed, two large branches exactly corresponding to Groups I and II were recognized (Fig. 3).

TABLE 4. Matrices of Nei's (1978) unbiased genetic distance (above diagonal) and modified Rogers' distance (Wright, 1978) (below diagonal) among eight samples and two subsamples of Hynobius naevius analyzed. Sample/subsample numbers correspond to those in Table 1.

\begin{tabular}{ccccccccccc}
\hline Sample/subsample & 1 & 2 & 3 & 4 & $5-1$ & $5-2$ & 7 & 8 & 9 & 10 \\
\hline 1 & & 0.002 & 0.044 & 0.054 & 0.043 & 0.801 & 0.030 & 0.024 & 0.697 & 0.679 \\
2 & 0.060 & & 0.046 & 0.045 & 0.040 & 0.789 & 0.033 & 0.027 & 0.683 & 0.669 \\
3 & 0.203 & 0.206 & & 0.099 & 0.038 & 0.652 & 0.023 & 0.019 & 0.538 & 0.573 \\
4 & 0.228 & 0.210 & 0.299 & & 0.061 & 0.718 & 0.073 & 0.081 & 0.614 & 0.619 \\
$5-1$ & 0.199 & 0.193 & 0.190 & 0.239 & & 0.674 & 0.021 & 0.031 & 0.567 & 0.576 \\
$5-2$ & 0.719 & 0.709 & 0.667 & 0.686 & 0.670 & & 0.686 & 0.715 & 0.027 & 0.031 \\
7 & 0.172 & 0.178 & 0.154 & 0.260 & 0.148 & 0.677 & & 0.000 & 0.587 & 0.592 \\
8 & 0.152 & 0.162 & 0.141 & 0.272 & 0.172 & 0.690 & 0.049 & & 0.607 & 0.602 \\
9 & 0.677 & 0.667 & 0.614 & 0.641 & 0.621 & 0.181 & 0.632 & 0.643 & & 0.021 \\
10 & 0.668 & 0.658 & 0.625 & 0.640 & 0.622 & 0.195 & 0.630 & 0.638 & 0.159 & \\
\hline
\end{tabular}




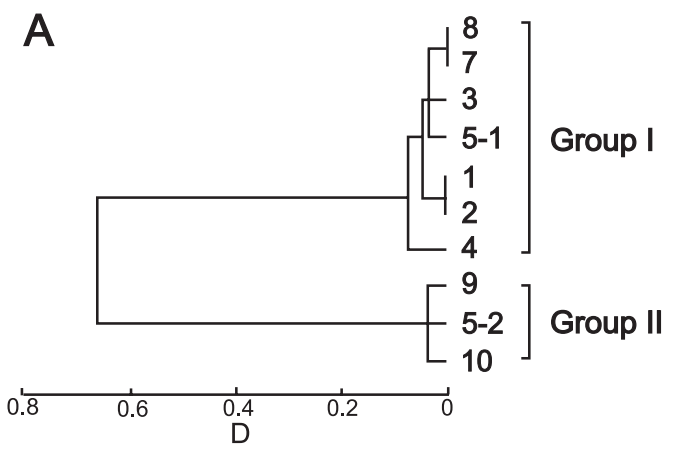

B

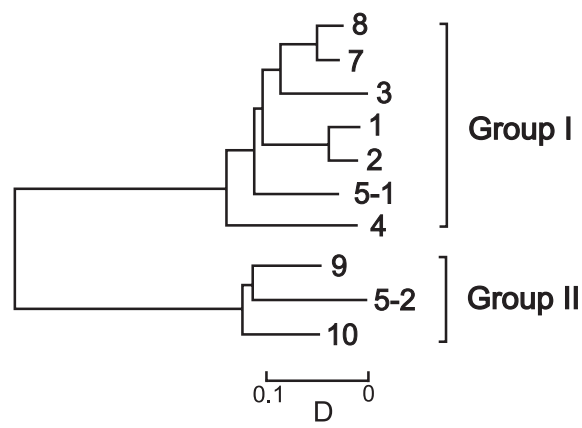

FIG. 3. UPGMA phenogram based on Nei's (1978) unbiased genetic distances (A) and neighborjoining tree (rooted at the midpoint of the longest path) based on modified Rogers' distance (Wright, 1978) (B) among eight samples and two subsamples of Hynobius naevius studied.

With respect to the adult morphological characteristics, Groups I and II completely corresponded to the types showing larger body size and unmottled bluish purple dorsum, and smaller body size and brownish white mottling on reddish purple dorsum, respectively.

Sample 8 (ASO) from the inner slope of the Aso caldera belonged to Group I. Within this group, ASO was genetically closest to the geographically closest Sample 7 (KIKUCHIKEIKOKU) with extremely small genetic distances (Nei's $\mathrm{D}=0.000$, modified Rogers' $\mathrm{D}=0.049$ ). The two samples did not differ significantly in allelic frequencies at any polymorphic loci examined ( $\chi^{2}$-test, $\left.\mathrm{P}>0.05\right)$.

\section{DISCUSSION}

The present results indicate that the sala- manders from central Kyushu, currently identified as $H$. naevius, actually include two genetically, morphologically, and ecologically distinct groups and that their representatives occur sympatrically at least in KIKUKA (locality number 5 in Fig. 1). These findings are comparable to a case of sympatric occurrences of two $H$. naevius types in northern Kyushu reported by Tominaga et al. (2003). From comparisons of our genotypic, morphological, and ecological data with those given by Tominaga et al. (2003), it is obvious that our groups I and II correspond to their types A and $\mathrm{B}$, respectively. These two groups are considered to represent two distinct species, because even in areas of sympatry they showed complete allelic displacements at five (in central Kyushu: this paper) or two loci (in northern Kyushu: Tominaga et al., 2003).

Mechanisms responsible for the reproductive isolation between Groups I and II are yet to be studied. From the cases of other loticbreeding Hynobius species from Kyushu (Sengoku et al., 1996), breeding seems to occur in spring in both groups. Although we could not find eggs for either group, Group I females having mature eggs were found in the streams, where we also found larvae of the same group throughout the year. On the other hand, in spite of our intensive field survey, we could not find any larvae or just metamorphosed individuals of Group II in the same streams in any season. Instead, females of Group II with seemingly mature eggs were found under the ground far from the streams. These findings suggest a possible differentiation in breeding environment between the two groups. A similar situation has been reported for the salamanders in northern Kyushu by Tominaga et al. (2003), who suggested from field observations that their type B (=Group II of this study) breeds underground. Elucidating the breeding habits of this group in central Kyushu is one of the most important tasks to be achieved.

In northern Kyushu, Tominaga et al. (2003) found much wider occurrence of Group I (for identification, see above) than Group II, while 


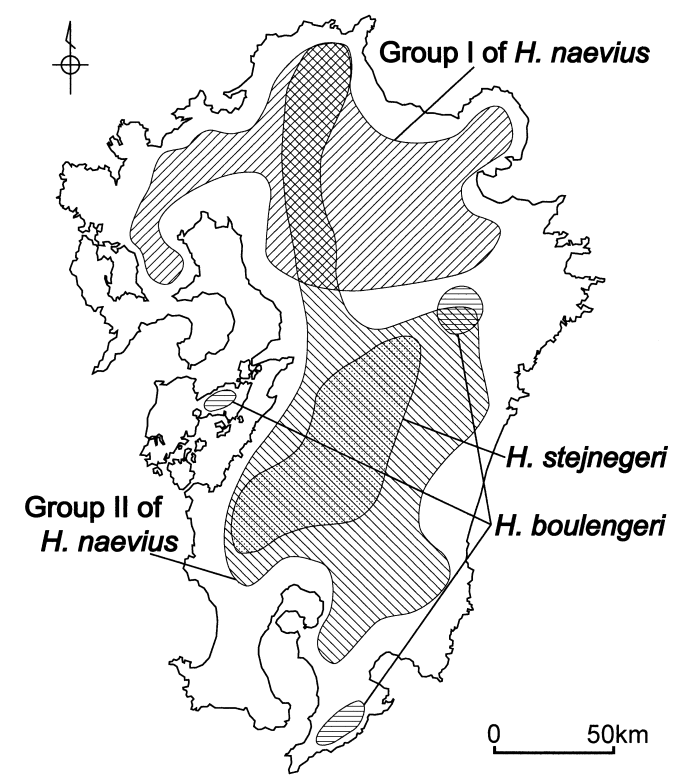

FIG. 4. A map of Kyushu, showing ranges of distributions of lotic-breeding Hynobius. Data for distributional ranges of $H$. boulengeri and $H$. stejnegeri were taken from Nishikawa et al. (2001, 2003).

Sato et al. (1994) reported the presence of Group I in northern and central Kyushu, and of Group II in southern Kyushu. In western central Kyushu where our survey was carried out, specimens of Group I were found only in the northern localities, while those of Group II were found in both northern and southern localities. Judging from these lines of distribution, we suspect that Group I is distributed from northern to central Kyushu, while Group II is mainly distributed in southern Kyushu and partially in central and northern Kyushu, with limited sympatry with Group I in the latter two regions (Fig. 4).

As already noted by Tominaga et al. (2003), lotic-breeding salamanders from Kyushu show interesting distributions; the larger type of $H$. naevius (Group I), $H$. boulengeri, and $H$. stejnegeri are entirely allopatric with each other, while the smaller type of $H$. naevius (Group II) is occasionally sympatric with them (Fig. 4). The former three salamanders are all larger than the latter and are known to breed in streams, whereas available data suggest underground breeding of Group II salamanders. Such difference in breeding environment might be playing an important role in enhancing a premating isolation (Mayr, 1963) between them. Also, this difference, along with divergence in body size, may lead to resource partitioning in both larvae and adults through segregation in microhabitat, enabling them to coexist in some parts of Kyushu. These assumptions need verification by future field studies.

Population 8 (ASO) inhabiting the inner slope of Aso Volcano was genetically closest to the geographically nearest population (Population $7=\mathrm{KIKUCHI}-\mathrm{KEIKOKU)} \mathrm{with} \mathrm{only}$ slight genetic differentiation. According to the geological evidence (Machida et al., 2001), the past four pyroclastic flows produced by volcanic eruptions of Aso severely destroyed the surrounding environment. Shimoyama et al. $(1994,1995)$ argued that the last pyroclastic flow ca. 85,000 years ago, reaching over 400C in temperature, ruined the surrounding forests by roasting them. If this is the case, the salamander population ancestral to Population 8 is most likely to have dispersed into the current caldera area quite recently. Except for localities 8 (this study) and 12 [record in Environmental Agency of Japan (1979)], there are no records of $H$. naevius in the regions surrounding Aso Volcano. This may reflect the severe destruction of habitats of the salamander by the past pyroclastic flows of Aso and its recent slow re-migration from the neighboring area. The results of our genetic investigation support this view.

Tominaga et al. (2003), while considering their types A and B as corresponding to the northern and southern Kyushu types (Sato et al., 1994), respectively, rejected the validity of the central Kyushu type of Sato et al. (1994). However, samples of salamanders from central Kyushu examined by Tominaga et al. (2003) were very limited in number. In the present study, we surveyed many more samples from central Kyushu than these authors, but still failed to find the central Kyushu type, which is, 
according to Sato et al. (1994), characterized by a large body size and mottled dorsum. It is almost certain that there are only two types of $H$. naevius at least in northern Kyushu and the western part of central Kyushu. However, with respect to the salamander populations in the eastern part of central Kyushu, data available to us are still insufficient to negate the validity of the central Kyushu type, and further survey in the eastern part is required.

\section{ACKNOWLEDGMENTS}

We thank T. Matsuzaka for facilitating this study, Y. Hase for valuable comments on the manuscript, K. Sakata and H. Kaoka for help in collecting the specimens, and T. Johnson for linguistic improvement of the manuscript. The senior author thanks S. Shiraishi, T. Takamiya, and A. Tominaga for their continuous encouragements. We also thank two anonymous referees for valuable comments on an earlier version of the manuscript.

\section{LITERATURE CITED}

Ayala, F. J., J. R. Powel, M. L. Tracey, C. A. Mourão, AND S. PÉreZ-SALAS. 1972. Enzyme variability in the Drosophila willistoni group. IV: Genetic variation in natural populations of Drosophila willistoni. Genetics 70: 113-139.

Boyers, S. H., D. C. FAINER, AND E. J. WATSONWILLIAMS. 1963. Lactate dehydrogenase variation from human blood: evidence for molecular subunits. Science 141: 642-643.

Clayton, J. W. And D. N. TRetiak. 1972. Aminecitrate buffers for $\mathrm{pH}$ control in starch gel electrophoresis. J. Fish. Res. Board Canada 29: 1169-1172.

ENVIRONMENTAL AGENCY OF JAPAN. 1979 (1978). Report of Reptiles and Amphibians Survey of the Second National Survey on the Natural Environment in 1978. Kumamoto Prefecture, Kumamoto. (in Japanese)

FeLSENSTEIN, J. 1993. PHYLIP (Phylogeny Inference Package) version 3.5c. Distributed by the author. Univ. Washington, Seattle.

HARRIS, H. AND D. A. HOPKINSON. 1976. Hand- book of Enzyme Electrophoresis in Human Genetics. North-holland, Amsterdam.

IUBMB (INTERNATIONAL UNION OF BIOCHEMISTRY AND MOLECULAR BIOlOGY). 1992. Enzyme Nomenclature 1992. Academic Press, San Diego, CA.

LEVENE, H. 1949. On a matching problem arising in genetics. Annal. Math. Stat. 20: 91-94.

MACHIDA, H., Y. OTA, T. KAWANA, H. MORIWAKI, AND S. NAGAOKA (eds.). 2001. Regional Geomorphology of the Japanese Islands, Vol. 7, Geomorphology of Kyushu and the Ryukyus. Univ. Tokyo Press, Tokyo. (in Japanese)

MAYR, E. 1963. Animal Species and Evolution. Belknap Press of Harvard University Press, Cambridge, Massachusetts.

MurPhy, R. W., J. W. Sites, Jr., D. G. Bush, AND C. H. HAUFLER. 1996. Proteins: Isozyme electrophresis. p. 51-120. In: D. M. Hillis, C. Moriz, and B. K. Mable (eds.), Molecular Systematics. Sinauer Associates, Massachusetts.

NEI, M. 1978. Estimation of average heterozygosity and genetic distance from a number of individuals. Genetics 89: 583-590.

Nishikawa, K., M. Matsui, S. TANABE, AND S. SATO. 2001. Geographic enzyme variation in a Japanese salamander, Hynobius boulengeri Thompson (Amphibia: Caudata). Herpetologica 57: 281-294.

Nishikawa, K., M. Matsui, S. TANABE, AND M. SAKAMOTO. 2003. Occurrence of a lotic breeding Hynobius salamander (Amphibia, Urodela) on Kamishima of the Amakusa islands, Japan. Cur. Herpetol. 22: 1-8.

SAITOU, N. AND M. NEI. 1987. The neighborjoining method: a new method for reconstructing phylogenetic tree. Mol. Biol. Evol. 4: 406-425.

SATO, I. 1943. A Monograph of the Tailed Batrachians of Japan. Nippon Shuppan-Sha, Osaka. (in Japanese)

SATO, S. 1954. On Pachypalaminus boulengeri Thompson from Kyushu. Dobutsugaku Zasshi (Zool. Mag.) 63: 195-199. (in Japanese with English abstract)

SAto, S., M. Kuramoto, AND Y. ONO. 1994. Morphological variation in Hynobius naevius (Caudata: Hynobiidae) in Kyushu, Japan. Jpn. J. Herpetol. 15: 199-125. 
SATO, S. 2003. From my old field notes (2) The first encounter with Hynobius boulengeri (Caudata: Hynobiidae) in the Osumi Peninsula. Bull. Herpetol. Soc. Japan 2003: 8-14. (in Japanese)

SElANDER, R. K., M. H. SMITH, S. Y. YANG, W. E. JOHNSON, AND J. B. GENTRY. 1971. Biochemical polymorphism and systematics in the genus Peromyscus. I. Variation in the old-field mouse (Peromyscus polionotus). Univ. Texas Publ. 7103: 49-90.

Sengoku, S., T. Hikida, M. MATSUi, AND K. NAKAYA (eds.). 1996. The Encyclopedia of Animals in Japan. Vol. 5: Amphibians, Reptiles, Chondrichthyes. Heibonsha, Tokyo. (in Japanese)

SHAw, C. R. AND R. PRASAD. 1970. Starch gel electrophoresis of enzymes-a compilation of recipes. Biochem. Genet. 4: 297-330.

Shimoyama, S., K. Watanabe, T. Nishida, D. HARADA, K. TSURUTA, AND Y. KOMATSU. 1994. Burnt big trees by the Aso-4 pyroclastic flow: Late Pleistocene trees found at Kamimine, Saga Prefecture, west Japan. Quaternary Res. 33: 107-112. (in Japanese)

Shimoyama, S., N. Matsumoto, T. Kuroda, K.
Takemura, R. Hamamoto, C. Mizota, K. FAURE, AND T. NISHIDA. 1995. Paleoenvironment of the Late Pleistocene in the Chikushi Plain, west Japan. Sci. Rep. Dept. Earth and Planet. Sci., Kyushu Univ. 19: 53-79. (in Japanese with English abstract)

SNEATH, P. H. A. AND R. R. SOKAL. 1973. Numerical Taxonomy. W. H. Freeman, San Francisco.

SwOFFORD, D. L. AND R. B. SElANDER. 1981. BIOSYS-1: a Fortran program for the comprehensive analysis of electrophoretic data in population genetics and systematics. J. Hered. 72: 281-283.

TominagA, A., M. MAtsui, K. NishiKAwA, AND S. SATO. 2003. Occurrence of two types of Hynobius naevius in northen Kyushu, Japan (Amphibia: Urodela). Zool. Sci. 20: 1467-1476.

WRIGHT, S. 1978. Evolution and the Genetics of Population, Vol. 4. Valiability within and among Natural Populations. Univ. Chicago Press, Chicago.

Accepted: 22 September 2005 